\title{
WORKSHOP HIGHER ORDER THINGKING SKILLS BAGI GURU SMK DI DKI JAKARTA
}

\author{
Uswatun Hasanah' ${ }^{1)}$, Agus Dudung ${ }^{2)}$, Sugeng Priyanto ${ }^{3)}$ \\ Fakultas Teknik, Universitas Negeri Jakarta \\ E-mail: us_nina@yahoo.com ${ }^{1)}$, agusdudung65@gmail.com²)
}

\begin{abstract}
The purpose of this Activity is to provide good quality HOT test quality training seen from: (a) Validity and reliability of the test (b) Grain analysis to see the difficulty index and Different power. Target Audience in this activity is the teachers of SMK in Jakarta, who really interested and have the potential to develop. The number of active participants is 25 vocational teachers. The participant will then transfer the training activities to the other teachers through each school. The type of activity material is this training theory and practice, with $20 \%$ theory composition and $80 \%$ practice covering aspects of data analysis techniques with computer assistance through SPSS program and ITEMAN program. Theory is given before engaging in practical activities or integrated during the direct practice by the participants. Based on the results of the exercises made some conclusions. There are two aspects of training materials provided to teachers in Jakarta, namely the technical aspects of HOT problem making skills and aspects of ITEMAN program use. Based on the evaluation that has been implemented, from the technical aspect, this training can be quite successful. Over $90 \%$ of participants mastered the material well, this training can be quite successful. Given the time of limited service activities. Nevertheless, in general, this service activity received a positive response from the teachers especially trainees, and schools in general. In relation to the implementation of this activity, suggestions may be made: (a) For the trainee's teachers, the knowledge and skills possessed should be developed on their own. The way that can be taken for example, teaching in a relavan. (b) For the implementing team of dedication activities, to be considered for holding the same training but with more in-depth material in the coming year. The goal is to achieve the desired end goal. namely to make the professional teachers in the field. (c) It is good that teachers continue to develop practical practices in schools.
\end{abstract}

Keywords: Assessment and item about Higher Order Thingking Skills

\begin{abstract}
ABSTRAK
Tujuan Kegiatan ini adalah Untuk memberikan pelatihan pembuatan kualitas tes HOT yang baik dilihat dari: (a) Validitas dan reliabilitas tes (b) Analisis butir untuk melihat indeks kesukaran dan Daya beda. Khalayak Sasaran dalam kegiatan ini adalah para Guru SMK di Jakarta, yang betul-betul berminat dan mempunyai potensi untuk berkembang. Jumlah peserta yang aktif adalah 25 Guru SMK. Peserta itu nantinya akan mentransfer kegiatan pelatihan tersebut ke para guru yang lainnya lewat masing-masing sekolah. Jenis materi kegiatan adalah pelatihan ini teori dan praktek, dengan komposisi $20 \%$ teori dan $80 \%$ praktek yang mencakup aspek teknik analisis data dengan bantuan komputer melalui program SPSS dan program ITEMAN. Teori diberikan sebelum melakukan kegiatan praktek atau diintegrasikan selama praktek langsung oleh peserta. Berdasarkan hasil latihan yang dilakukan didapat beberapa kesimpulan, Terdapat dua aspek materi pelatihan yang diberikan terhadap para guru di Jakarta, yaitu aspek teknik keterampilan pembuatan soal HOT dan aspek penggunaan program ITEMAN. Berdasarkan evaluasi yang telah dilaksanakan, dari aspek teknik, pelatihan ini dapat dikatakan cukup berhasil. Lebih dari 90\% peserta menguasai materi dengan baik, pelatihan ini dapat dikatakan cukup berhasil. Mengingat waktu kegiatan pengabdian yang terbatas. Namun demikian secara umum kegiatan pengabdian ini mendapat respons yang positif dari para guru peserta pelatihan khususnya, dan sekolah pada umumnya. Berkaitan dengan pelaksanaan kegiatan ini, saran yang dapat disampaikan: (a) Bagi para guru peserta latihan, bekal pengetahuan dan keterampilan yang telah dimiliki ini hendaknya dikembangkan sendiri. Cara yang dapat ditempuh misalnya, mengajar dibidang yang relavan. (b) Bagi tim pelaksana kegiatan pengabdian, supaya dipertimbangkan untuk mengadakan pelatihan yang sama namun dengan materi yang lebih mendalam di tahun mendatang. Tujuannya adalah agar tercapainya tujuan akhir yang diharapkan. yaitu menjadikan para guru yang professional pada bidangnya. (c) Ada baiknya para guru tetap mengembangkan latihan-latihan praktik di sekolah.
\end{abstract} Kata kunci: Penilaian dan butir soal Higher Order Thingking Skills 


\section{PENDAHULUAN}

\section{A. Analisis Situasi}

Salah satu yang menentukan prestasi belajar siswa adalah guru. Peranan guru sangat menentukan terselenggaranya proses belajar mengajar yang berkualitas dan relevan. Oleh sebab itu guru dituntut untuk mampu melaksanakan tugas profesionalnya dengan baik dan bertanggung jawab. Tugas tersebut meliputi membuat dan menyusun prosedur penilaian, menyeleksi dan mengurutkan tujuan pengajaran berdasarkan materi pelajaran, pengelolaan proses belajar mengajar serta mengelompokan siswa dalam kelompok atau kegiatan yang berbeda. Agar dapat berperan bukan hanya pemberi ceramah dan penyaji informasi, tetapi. juga dalam merencanakan, mengelola dan mengawasi PBM, guru dituntut menguasai materi pelajaran, menggunakan berbagai model belajar yang relevan dengan materi. pelajaran, mengenal siswa sebagai pelajar dan manusia yang menuju kedewasaannya serta memahami peranan sekolah dalam keseluruhan proses pembangunan masyarakat seluruhnya dan manusia Indonesia seutuhnya. Selain itu guru juga diharapkan dapat mengembangkan berbagai jenis dan bentuk evaluasi belajar, menafsirkannya untuk penilaian dan bimbingan belajar siswa, Dalam hal ini guru dituntut harus mampu menyusun tes yang berkualitas dan mampu memprediksi prestasi siswa yang sebenarnya. Dengan demikian dalam menafsirkan hasil tes tersebut, guru tidak mengalami kesalahan atau kekeliruan.

Untuk melaksanakan tugas profesional di atas, guru dituntut untuk memiliki delapan faktor yang menentukan kemampuan guru dalam menyelenggarakan PBM yang baik, efesien dan efektif. Faktor-faktor tersebut, yaitu tipe pendidikan, kebaharuan pendidikan, ijasah, masa jabatan, pengalaman mengajar, tugas mengajar dan alokai waktunya, kemampuan verbal, dan karakteristik pribadi guru (jenis kelamin, suku, status). Berdasarkan penelitian yang diambil dari hasil tes para siswa setelah dianalisis butir ternyata soal-soal tes yang dibuat oleh para guru masih belum mampu membuat tes yang baik. Dari penelitian tersebut maka perlu adanya pendalaman tentang pembuat tes yang baik bagi para guru. Dengan mempertimbangkan hal di atas, dapat diketahui betapa pentingnya kualitas tes. Tes yang berkualitas menjadi alat yang valid dan reliabel dalam mengukur kemampuan belajar siswa. Dengan demikian permasalahan kealitas tes penting untuk dipahami oleh para guru SMK.

Kegiatan ini diharapkan menjadi informasi yang bermanfaat bagi Kanwil Depdikbud, tentang kompetensi guru dalam menyusun tes pelajaran. Hal ini dapat menjadi bahan pertimbangan untuk perbaikan yang perlu dilakukan guna peningkatan kemampuan guru dalam menyusun tes yang HOT.

Berdasarkan uraian yang telah dijelaskan pada analisis situasi, permasalahan utama yang muncul adalah masih adanya para guru yang belum memahami tentang analisis butir tes yag HOT. Pertanyaan-pertanyaan lain yang dapat diidentifikasi, antara lain adalah bagaimana peranan guru dalam penyususn tes? Bagaimana teknis yang digunakan guru dalam menyusun tes untuk masing-masing pelajaran? Apakah guru-guru menyusun tes berdasarkan pengalaman pribadi? Apakah guru pernah mengevalusi tes buatan sendiri? Dari pertanyaan-pertanyaan di atas maka dirumuskan masalah tersebut:

\section{B. Perumusan Masalah}

Bagaimana meningkatkan kualitas tes HOT buatan guru di DKI Jakarta?

\section{TINJAUAN PUSTAKA}

Agar mutu pendidikan sesuai dengan apa yang diharapkan oleh masyarakat atau pengguna maka perlu ada standar yang diajadikan acuan (Agus Dudung, 2017: 87). Standart dalam Tes sangat diperlukan agar mutu pendidikan terjamin, selanjutnya tes adalah alat untuk memperoleh data tentang perilaku individu (Allen \& Yen, 1979). Karena itu, di dalam tes terdapat sekumpulan pertanyaan yang harus dijawab atau tugas 
E-ISSN: 2597-8926

yang harus dikerjakan, yang akan memberikan informasi mengenal aspek psikologis tertentu berdasarkan jawaban individu yang dikenai tes tersebut (Anastasi,1982).

Selanjutnya Anastasi (1982) menyatakan bahwa tes merupakan pengukuran yang obyektif dan standard. Cronbach yang dikutip Rush (1988) menambahkan bahwa tes adalah prosedur yang sistematis guna mengobservasi dan memberi deskripsi sejumlah atau lebih ciri seseorang dengan bantuan skala numerik atau suatu sistem katagoris.

Dengan demikian dapat dinyatakan bahwa tes adalah prosedur yang sistematis. Ini berarti butir tes disusun berdasarkan cara dan aturan tertentu, pemberian skor harus Jelas dan dilakukan secara terperinci, serta individu yang menempuh tes tersebut harus mendapat butir tes yang sama dan dalam kondisi yang sebanding (Azwar. 1987).

Selain itu tes berisi sampel perilaku, yang berarti kelayakan tes bergantung pada sejauh mana butir tes mewakili secara representatif kawasan dan hal yang diukur. Kemudian, bagaimanapun banyaknya butir dalam tes tersebut, isi tes tidak akan melebihi seluruh butir tes yang ada. Perilaku yang diukur tes adalah jawaban yang diberikan subyek terhadap tes. Jawaban subyek ini menjadi indikator yang menunjukkan hal yang telah dipelajari subyek.

Jadi, tes merupakan alat bantu untuk mengukur perilaku, terdiri atas pertanyaan (butir) yang berguna sebagai penjaring informasi perilaku yang dimiliki individu. Karena itu, tes yang disusun diharapkan merupakan tes yang berkualitas tinggi sehingga diperoleh informasi yang obyektif dan mewakihi perilaku yang dikehendak.

Tes untuk mengukur prestasi belajar siswa diklasifikasikan dalam tes yang mengukur kemampuan khusus (Anastasi, 1982). Salah satu tes prestasi yang selalu digunakan untuk mengukur prestasi belajar siswa adalah tes pelajaran yang disusun oleh guru sendiri.

Tes prestasi belajar ini yang paling signifikan peranannya adalah pada program pengajaran di sekolah. Jadi tes ini menjadi bagian integral proses belajar mengajar dan berpengaruh langsung terhadap perkembangan belajar siswa. Jadi dapatlah dinyatakan bahwa tes pelajaran buatan guru adalah tes yang paling dominan dan banyak digunakan (Gronlund, 1982). Selanjutnya Gronlund juga merumuskan beberapa prinsip dasar pengukuran prestasi belajar, yaitu tes harus mengukur hasil belajar yang sesuai dengan tujuan pengajarar, yang merupakan sampel yang representatif dari materi pelajaran, berisi butir tes dengan tipe yang paling tepat, dirancang sesuai tujuan, mempunyai reliabilitas dan validitas yang baik sehingga hasilnya ditafsirkan dengan tepat guna, meningkatkan prestasi belajar siswa.

Menurut pendapat Ebel yang dikutip Karmel dan Karmel (1978) terdapat sepuluh kriteria tes yang baik, yaitu: Pertama, tes harus relevan. Ini berarti tes harus mengukur perilaku yang ingin diukur. Hal ini menyangkut validitas tes (Pophan, 1981; Suryabrata, 1983). Jadi, isi tes (butir pertanyaan yang dibuat) harus mengukur suatu perilaku tertentu dan disusun berdasarkan indikator dan perilaku yang akan diukur tersebut.

Konsep validitas mengacu pada interpretasi yang diperoleh melalui hasil, disimpulkan dari fakta yang diperoleh (seleksi dan penenempatan) dan dinyatakan. dalam tingkatan (tinggi, sedang dan rendah) (Gronlund, 1982).

Validitas merupakan bagian yang terpenting dan kualitas tes. Hal ini dapat diperhatikan melalui pertanyataan yang dikemukakan Ebel. (1979), yaitu validitas merupakan bagian terpenting yang harus dimiliki sebuah tes, mengacu pada keefektifan tes dalam mengukur tujuan, mernpunyai berbagai aspek, bentuk dan didefinisikan dengan bermacarn cara, diperoleh dengan uji coba tes yang dibuat dan untuk menyatakannya, seseorang harus mernpunyai kriteria ukuran yang nyata, sintetis dan hipotetis.

Jurnal Sarwahita Vol. 14 No. 02 Tahun 2017 | 134 
Validitas tes dibedakan atas beberapa tipe yaitu validtas isi, validitas konstrak dan validitas kriteria.

\section{A. Validitas Isi}

Validitas isi igunakan untuk situasi dimana pemakai tes akan menarik kesimpulan domain butir tes berdasarkan sekor tes individu ke domain butir yang lebih besar yang serupa dengan butir-butir yang terdapat dalam tesnya sendiri (Crocker \& Algina, 1986; Nur, 1987).

Dari keterangan di atas dapat dinyatakan bahwa validitas isi digunakan untuk menjawab pertanyaan bagaimana ketepatan isi tes untuk mewakili seluruh perilaku yang akan diukur (Gronlund, 1982). Dalam hal, ini tentu saja digunakan analisis rasional dan ditentukan sendiri oleh individu. Jadi merupakan justifikasi yang bersifat subjektif (Allen \& Yen, 1979). Meskipun demikian, validitas isi adalah hal pertama yang harus ditegakkan dalam mengembangkan tes.

Validitas isi merupakan hal yang penting dipertimbangkan guru dalam rnenyusun tes. Jika butir tes sudah mewakili materi pelajaran dan tujuan instruksional pengajaran yang akan dicapai (TIU dan TIK) maka dapat dinyatakan bahwa tes tersebut sudah memiliki validitas isi yang baik (Karmel \& Karmel, 1978). Yang harus dipertimbangkan agar sebuah tes memiliki validitas isi, antara lain tujuan, susunan pemilihan butir, aspek yang diuji oleh butir dan kesimpulan dan hasil tes (perbandingan antara tujuan yang diharapkan dengan yang tercapai.

\section{B. Validitas Konstrak}

Validitas konstrak adalah sejauh mana hasil pengukuran dapat dianggap mencerminkan suatu konstrak psikologi (Allen \& Yen, 1979 dan Suryabrata, 1983). Konstrak adalah pengembangan ide untuk membuat kategorisasi dalam menentukan deskripsi perilaku dan perilaku ini tidak dapat dioservasi langsung. Jadi dapat dinyatakan bahwa konstrak adalah deskripsi keberadaan perilaku individu yang diukur berdasarkan kemampuan penalarannya, konstrak harus didefinisikan secara operasional. yaitu arti dan makna konstrak harus jelas, menetapkan aturan yang digunakan untuk rnengukurnya dan diukur melalui penjabaran bagaimana konstrak berhubungan dengan variabel lain.

Empat metode yang digunakan untuk menentukan validitas konstrak sebuah tes, yaitu korelasi antara konstrak yang diukur dengan kriteria penampilan tertentu, pendekatan perbedaan populasi, analisis faktor dan dengan menggunakan metode "Matrix Multitrait Multimethod" (Allen \& Yen, 1979)

\section{Validitas kriteria}

Validitas kriteria digunakan untuk:

Pertama. Menentukan bagaimana hasil tes memprediksi penampilan seseorang di masa yang akan datang (Validitas Prediktif) atau estimasi terhadap penampilan yang sekarang (Validitas Konkuren) terhadap satu atau beberapa nilai yang diukur (kriteria).

Kedua. Validitas ini dinyatakan dengan derajat hubungan antara skor tes dan kriteria yang diukur disebut koefisien validitas. Untuk menentukan tingkat koefisien validitas ini maka koefisien korelasi dikonsultasikan dengan grafik Flanagan (Maerun, 1982). Pada umumnya, jika korelasi antara kedua kriteria sama atau lebih besar dan 0,30 maka tes tersebut validitas yang baik. Beberapa permasalahan validitas yang berkenaan dengan kriteria, antara lain penentuan kriteria yang sesuai, ukuran sampel yang tidak mencukupi, pencemaran kriteria oleh individu, keterbatasan rentang skor dan tidak reliabelnya sekor kriteria (Crocker \& Algina, 1986). Untuk lebih membantu pemakai tes dalam mempertimbangkan validitas tes terhadap kriteria ini maka koefisien determinasi, kekeliruan baku, taksiran dan tabel ekspektasi perlu diketahui.

Ketiga. Keseimbangan antara tujuan yang ingin dicapai dengan jumlah butir tes yang mewakilinya. Di sekolah, tujuan yang ingin dicapal adalah TIK dan TIU. Jadi keseimbangan antara jumlah butir tes dengan kurikulum merupakan hal yang menentukan kualitas tes buatan guru.

Keempat. Efisiensi dan waktu yang dibutuhkan untuk melakukan tes, penskoran dan pengadministrasian skor tes tersebut. 
Dengan demikian, akan diperoleh keefektifan dalam mengadministrasikan hasil tes. Dalam tes buatan guru sekolah dasar sudah ditentukan batasan waktu yang diberikan pada siswa untuk menyelesaikan tes. Sehingga siswa harus memanfaatkan waktu seefektif dan seefisien mungkin. Jadi tes buatan guru adalah kombinasi tes kekuatan (Power Test) dan tes kecepatan (Speed Test). Tes ini selain mengetahui seberapa jauh pemahaman, pengetahuan dan pengertian siswa terhadap pelajaran, juga kecepatan siswa mnjawab tes menentukan keberhasilannya (Rush, 1988).

Kelima. Objektivitas dalam memberikan sekor dan interpretasinya. Pemberian sekor terhadap hasil ujian siswa biasanya sudah ditentukan pedoman yang baku. Akan tetapi, Karena untuk sekor tes esei masih menggunakan rentangan sekor, sedangkan untuk tes objektif tidak maka nilai sekor yang diperoleh siswa untuk tiap permeriksa akan berbeda. Dengan adanya kebijakan untuk membuat dan memeriksa tes oleh guru di sekolah maka objektivitas skor siswa dapat dianggap baik. Hal ini dengan mempertimbangkan bahwa guru sudah mengenal karakteristik siswanya sendiri. Kelima, kekhususan tes yang mengukur materi pelajaran yang diajarkan di kelas. Hal ini untuk membedakan siswa yang sudah belajar dengan siswa yang belum. Sehingga dapat dinyatakan siswa yang berhasil mengerjakan tes tersebut sudah belajar materi pelajaran tersebut. Inilah sifat khusus yang harus dimiliki tes yang disusun guru, sehingga merupakan cermin penguasaan pelajaran oleh siswa.

Keenam. Tingkat kesukaran setiap butir tes. Ebel (1979) berpendapat bahwa jika lebih separuh siswa berhasil menye lesaikan tes maka butir tes memihiki kesukaran yang baik. Jadi kesukaran butir ditinjau berdasarkan proporsi keberhasilan siswa menjawab benar butir tes tersebut. Permasalahan yang dihadapi dalam pembuatan tes adalah menentukan taraf kesukaran maksimum butir. Dan hasil penelitian, semakin dekat taraf kesukar butir menuju proporsi 0,50 maka semakin baik tes tersebut (Crocker \& Algina, 1986). Berdasarkan tabel hubungan kesukaran butir dengan indeks daya beda maka diperoleh kesukaran menengah terletak pada 0,25 - 0,75. (Allen, 1979).

Ketujuh. Kemampuan butir untuk membedakan kelompok siswa yang mempunyai kemampuan tinggi dan rendah (daya beda).

Untuk mengukur daya beda digunakan korelasi point biserial yaitu korelasi sekor soal (data dikotomi 1 dan 0) dengan skor total diperoleh siswa untuk butir tertentu. Teknik yang lain adalah korelasi biserial. Keunggulan teknik ini adalah nilai signifikansinya ditentukan secara statistik.

Teknik yang lebih sederhana adalah penggunaan $27 \%$ kelompok atas dan $27 \%$ kelompok bawah. Pembagian tersebut memberikan efisiensi tertinggi dalam memperkirakan daya beda soal (Gronlund, 1982).

Untuk menginterpretasikan baik atau buruknya indeks daya beda dan setiap butir tes yang dibuat digunakan kriteria "rules of thumb" dan Ebel seperti yang dikutip Stanley dan Hopkins (1978), Crocker dan Algina (1986) dan Nur (1988). Kriteria yang digunakan adalah seperti yang tercantum pada tabel berikut ini.

Tabel 1. Kriteria Indeks Daya Beda

\begin{tabular}{|c|c|}
\hline Indeks Daya Beda & Evaluasi Butir Tes \\
\hline 0,40 ke atas & Butir sangat baik \\
\hline $0,30-0,39$ & Butir baik \\
\hline $0,20-0,29$ & Butir perlu direvisi/diperbaiki \\
\hline 0,19 ke bawah & Butir tidak baik, disisihkan atau direvisi total \\
\hline
\end{tabular}

Kedelapan. Reliabilitas, suatu tes dikatakan reliabel jika hasil pengukurannya sama atau hampir sama jika pengukurannya dilakukan oleh orang yang sama pada waktu

Jurnal Sarwahita Vol. 14 No. 02 Tahun 2017 | 136 
yang berlainan. Jadi dapat dinyatakan bahwa tes tersebut harus konsisten pada kondisi yang berbeda. Pada umumnya, reliabilitas disebut koefisien reliabilitas.

Reliabilitas mengacu pada seberapa jauh kesalahan pengukuran yang sistematik teriadi. Jadi sebuah pengukuran dinyatakan reliabel, jika mengukur secara konsisten variasi kondisi yang menghasilkan kesalahan pengukuran tersebut.

Koefisien reliabilitas merupakan korelasi antara pengukuran yang sama yang digunakan pada waktu yang berbe da, antara dua alat pengukuran yang setara, antara dua bentuk tes yang paralel dengan waktu yang berbeda, dan antara bagian dan alat pengukur yang sarana (Gronlund, 1982). Setiap cara di atas akan menghasilkan tipe reliabilitas yang berbeda, jadi tidak dapat dipertukarkan.

Jika sebuah tes diujikan sekali maka reliabilitas tes yang diperoleh disebut koefieien konsistensi internal. Koefisien stabilitas, koefisien ekivalen, koefisien stabilitas dan ekivalen, masing-masing untuk reliabilitas dan metode tes ulangan, metode bentuk setara dan metode tes ulangan setara.

Jadi untuk mnengestirnasi reliabilitas dapat ditentukan dengan koefisien stabilitas, koefisien ekivalensi, koefisien ekivalensi dan stabilitas serta koefisien konsistensi internal.

Untuk menghitung koefisien konsistensi internal tes dapat digunakan teknik SpearrnanBrown (jika digunakan metode belah dua atau ganjil-genap), teknik Flanagan, teknik Rulon, teknik Kuder Richardson (KR-20 dan KR-21) (untuk data yang dikotomi), koefisien Alpha dan analisis Hoyt.

Untuk menguji tinggi rendahnya reliabilitas digunakan klassifikasi Guilford (dalam Subino, 1987:115) kurang dan 0,20 tidak ada korelasi.

Tabel 2.

\begin{tabular}{|c|c|}
\hline $0,20-0,40$ & Korelasi rendah \\
\hline $0,40-0,70$ & Korelasi sedang \\
\hline $0,70-0,90$ & Korelasi tinggi \\
\hline $0,90-1,00$ & Korelasi sangat tinggi \\
\hline
\end{tabular}

Jika digunakan K-R 20 atau K-R 21 untuk tes standard maka koefisien yang diharapkan adalah 0.90 ke atas. Akan tetapi, untuk tes hasil belajar di kelas, koefisien reliabilitas yang baik terletak antara $0.60-0.80$.

Beberapa hal yang mempengaruhi reliabilitas tes adalah perbedaan kondisi individu, perbedaan kondisi tes, variasi mengadininistrasikan tes serta kesalahan dan perbedaan pemberian sekor. Panjang tes, kecepatan, homogenitas kemarnpuan siswa, tingkat kesukaran butir, juga mempengaruhi reliabilitas tes.

Kesembilan. Kejujuran dan pemerataan kesempatan. Ini menyangkut keadilan dalam pelaksanaan evaluasi. Aspek ini sukar diinterpretasikan secara operasional, tetapi dapat dipahami sebagai syarat mutlak yang harus dipenuhi dalam membuat sebuah tes.

Tes buatan guru umumnya memiliki faktor ini. Untuk menjawab, setiap siswa akan diberi kesempatan, waktu, soal, situasi dan 137 | Jurnal Sarwahita Vol. 14 No. 02 Tahun 2017 kondisi sekolah yang tidak berbeda. Jadi faktor ini telah dipunyai tes yang digunakan di sekolah. Kesepuluh, kecepatan menyelesaikan tes. Hal ini untuk menjawab pertanyaan apakah sekor yang diperoleh dipengaruhi oleh kecepatan dalam memberikan jawaban. Dalam evaluasi belajar formatif, sumatif dan perbaikan kecepatan hanya kecil peranannya dalam menentukan sekor siswa. Hal ini dengan mempertimbangkan bahwa tersedia waktu yang cukup dan sarana untuk siswa mengerjakan tes tersebut, kriteria di atas yang paling utama adalah reliabilitas, validitas, daya beda dan tingkat kesukaran tes. Kemudian, juga akan dinilai efektifitas distraktor pilihan jawab dan tes tersebut. Dengan menggunakan aturan umum bahwa kelompok yang memilih pengecoh rata-rata skornya harus lebih rendah dan pada skor rerata mereka yang memilih jawaban yang benar dan dengan mempertimbangkan distraktor jawaban dihilangkan atau direvisi 

memilihnya maka dapat diketahui keefektifan distraktor pilihan jawab itu.

\section{METODE KEGIATAN}

\section{A. Tujuan Kegiatan}

Untuk memberikan pelatihan pembuatan kualitas tes HOT yang baik dilihat dari:

1. Validitas dan reliabilitas tes

2. Analisis butir untuk melihat indeks kesukaran dan daya beda.

B. Manfaat Kegiatan

1. Bagi para peserta (sasaran), dapat meningkatkan kualitas sumberdaya manusia, dari semula tidak mengerti dalam membuat butir soal menjadi lebih pandai membuat soal yang baik.

2. Menambah pengetahuan tentang kualitas tes yang baik, sehingga para peserta diharapkan setelah mengikuti pelatihan ini. Dapat meningkatkan secara profesional.

\section{Khalayak Sasaran}

Khalayak sasaran yang ditetapkan sejak semula adalah para Guru SMK di Jakarta, yang betul-betul berminat berminat dan mempunyai potensi untuk berkembang yang berfungsi sebagai khalayak sasaran. Pembatasan khalayak ini juga mengingat keterbatasan waktu, tempat dan biaya yang tersedia. Jumlah peserta yang aktif adalah 25 Guru SMK. Peserta itu nantinya akan mentransfer kegiatan pelatihan tersebut ke para guru yang lainnya lewat masing-masing sekolah.

\section{Metode Kegiatan}

Jenis materi kegiatan adalah pelatihan ini teori dan praktek, dengan komposisi $20 \%$ teori dan $80 \%$ praktek yang mencakup aspek teknik analisis data dengan bantuan komputer melalui program SPSS dan program ITEMAN. Teori diberikan sebelum melakukan kegiatan praktek atau diintegrasikan selama praktek langsung oleh peserta.

\section{KERANGKA MASALAH}

Mengingat kondisi empiris yang telah digambarkan dalam analisis situasi dan permasalahan yang dikemukakan di atas, maka Mengingat kondisi empiris yang telah digambarkan dalam analisis situasi dan permasalahan yang dikemukakan di atas, maka

a. Pemecahannya dengan program pelatihan

b. Pelatihan yang tepat adalah memberikan pelatihan tentang analisisbutir soal tes dan teknik kalibrasi soal tes (iteman, analisis faktor).

c. Waktu pelatihan 16 Jam dengan perincian:

2 Jam Teori Tes.

8 Jam praktek latihan membuat soal tes.

6 Jam praktek latihan analisis butir soal tes.

d. Output pelatihan menghasilkan soal tes yang baku.

\section{PELAKSANAAN KEGIATAN}

A. Realisasi Pemecahan Masalah

Kegiatan pengabdian kepada masyarakat dalam bentuk pelatihan dan penyuluhan Kualitas Tes bagi guru SMK di DKI Jakarta. Telah berhasil dilaksanakan walaupun tidak semua rencana berjalan seperti yang diharapkan. Waktu pelaksanaan kegiatan dimulai pada:
Tanggal
: 26 - 27 September 2017
Jam
: 800 sampai 1630
Tempat
: FT- UNJ

\section{HASIL DAN PEMBAHASAN \\ A. Observasi Kegiatan}

Pada kegiatan ini diadakan observasi kegiatan terhadap peserta pelatihan dan evaluasi terhadap program pelatihan. Evaluasi terhadap peserta pelatihan dilalukan oleh anggota tim dengan membuktikan setiap peserta pelatihan telah mebuat butir soal yang valid dan reliabel. Evaluasi program kegiatan ini dilakukan untuk mengetahui tingkat ketercapian dari tujuan program kegiatan yang dilaksanakan. Kegiatan evaluasi dilaksanakan sebelum, selama dan sesudah kegiatan Jurnal Sarwahita Vol. 14 No. 02 Tahun 2017 | 138 
pelatihan berlangsung. Evaluasi sebelum kegiatan dilaksanakan dengan cara diskusi sebelum pemaparan materi dan sebelum pelaksanaan praktik. Sedang evaluasi selama kegiatan berlangsung dilakukan dengan mengamati para peserta pelatihan. Setelah itu dilakukan evaluasi dengan cara para peserta pelatihan membuat soal HOT. Dengan program ITEMAN, hasil praktik para peserta pelatihan untuk melihat keberhasilan, ternyata cukup memuaskan.

\section{B. Hasil Kegiatan}

Berdasarkan hasil pelatihan didapatkan suatu perubahan yang baik bagi para perserta guru guru, yang sebelumnya tidak begitu paham tentang ITEMAN. Sekarang memiliki kemampuan untuk membuat soal HOT dengan program ITEMAN di Sekolah tempat mengajar. Kegiatan pengabdian kepada masyarakat ini mempunyai beberapa hasil sebagai berikut:

1. Guru peserta pelatihan dapat meningkatkan kualitas sumberdaya manusia, dari semula tidak terampil menjadi lebih terampil dan mempunyai keahlian menjadikan guru yang professional.

2. Guru terampil dan guru yang berkualitas sesuai dengan bidangnya.

\section{KESIMPULAN DAN SARAN}

\section{A. Kesimpulan}

Terdapat dua aspek materi pelatihan yang diberikan terhadap para guru di Jakarta, yaitu aspek teknik keterampilan pembuatan soal HOT dan aspek penggunaan program ITEMAN. Berdasarkan evaluasi yang telah dilaksanakan, dari aspek teknik, pelatihan ini dapat dikatakan cukup berhasil. Lebih dari 90\% peserta menguasai materi dengan baik, pelatihan ini dapat dikatakan cukup berhasil. Mengingat waktu kegiatan pengabdian yang terbatas. Namun demikian secara umum kegiatan pengabdian ini mendapat respons yang positif dari para guru peserta pelatihan khususnya, dan sekolah pada umumnya.

\section{B. Saran}

Berkaitan dengan pelaksanaan kegiatan ini, saran yang dapat disampaikan:

1. Bagi para guru peserta latihan, bekal pengetahuan dan keterampilan yang telah dimiliki ini hendaknya dikembangkan sendiri. Cara yang dapat ditempuh misalnya, mengajar dibidang yang relavan.

2. Bagi tim pelaksana kegiatan pengabdian, supaya dipertimbangkan untuk mengadakan pelatihan yang sama namun dengan materi yang lebih mendalam di tahun mendatang. Tujuannya adalah agar tercapainya tujuan akhir yang diharapkan. yaitu menjadikan para guru yang professional pada bidangnya.

3. Ada baiknya para guru tetap mengembangkan latihan-latihan praktik di sekolah.

\section{DAFTAR PUSTAKA}

Anastasi. 1982. Psychological Testing. New York: McMillan Pub. Co. Inc.

Dudung, Agus. Studi Kepuasan stakeholder terhadap Layanan Program Studi di Universitas Negeri. Jakarta: Jurnal Kesejateraan Keluarga dan Pendidikan (JKKP). Vol.4 No.2 Oktober 2017.

Allen, Mary J. and Yen, Wendy M. 1979. Introduction to Measurement Theiry. Monterey, California: Books/Cole Pub. Co.

Azwar, Saifuddin. 1998. Tes Prestasi Belajar. Jakarta: Pustaka Pelajar.

Ebel, Robert L. 1979. Essentials of Educational Measurement. Englewood Cliffs, New Jersey: Prentice-Hall Inc.

Gronlund, Norma E., 1982. Constructing Achievement Test. Englewood Cliffs, New Jersey: Prentice - Hall Inc.

Karmel, Louis J. and Karmel, Marylin o. 1978. Measurement and Evaluation in The Schools. New York: Holt, Rinerhart and Winston Inc.

Suryabrata, Sumadi, 1983 Pengembangan Tes Hasil Belajar. Jakarta: Rajawali Press. 